\title{
Para ler a história da América Latina
}

PRADO, Maria Ligia \& PELLEGRINO, Gabriela. História da América Latina. São Paulo: Contexto, 2014. 206 p.

No ensino básico brasileiro, a América Latina aparece no contraponto e quase como "entidade". Nas discussões que competem à disciplina de história, em que figura com presença mais efetiva, é sempre trazida como contraste absoluto ou processo paralelo às experiências brasileiras. Pensar a emancipação, a formação dos estados nacionais, as políticas de massas e as ditaduras civil-militares no Brasil, oferece a oportunidade de espiar os hermanos para classificálas como dissidentes ou coincidentes. A diversidade de tensões, contradições e impasses, é reduzida a essa mirada, como se a ideia de América Latina pudesse concentrar as diversas histórias e estórias das nações que a compõem. Assim, na contramão deste olhar redutor e a partir de anos dedicados ao estudo da complexidade dos processos históricos Latino-Americanos, as historiadoras Maria Ligia Prado e Gabriela Pellegrino oferecem em seu livro, História da América Latina, uma leitura que amplia as discussões e enriquece os contrapontos possíveis entre as trajetórias diversas dos países ao sul do rio grande.

$\mathrm{Na}$ introdução do livro, as autoras pontuam o interesse de propiciar ao leitor brasileiro um "amplo quadro" da história da América Latina. Mas, se a ideia de uma amplitude de temas e discussões poderia supor ausência de profundidade nas discussões, a obra vai na direção contrária. O livro é dividido em doze capítulos que recortam grandes temas e períodos históricos. Após uma introdução, em que se discute a historicidade do nome e da ideia de América Latina, adentramos o capítulo intitulado "A crise dos domínios coloniais na América" e terminamos, depois de um logo percurso, com "Cultura e política na América Latina Contemporânea”. No entanto, estes grandes temas são trazidos pelas autoras em sua riqueza de conflitos, apresentando as principais questões, ideias políticas e culturais que estavam em voga, sem perder de vista os sujeitos desta história. Encontraremos aqueles cujos nomes nos sãos comuns, ainda que saibamos pouco de suas trajetórias, até outros que ficaram à margem das grandes narrativas históricas e que são recuperados pelas autoras, ilustrando a diversidade de vozes nos debates.

O primeiro capítulo começa com o desenlace trágico da história de um dos personagens mais interessantes e importantes do período colonial: Tupac Amaru. Depois de narrada sua brutal execução, as autoras comentam sua biografia, para então, a partir desta personagem, adentrar as tensões políticas e sociais no Vice-reino do Peru do século XVIII, ampliando em 
seguida o leque de discussões para o contexto colonial latino-americano.

Não por acaso é Tupac Amaru que abre as portas da história para o leitor. A força simbólica da rebelião liderada pelo descendente inca repercute política e culturalmente até hoje. Pensando esta repercussão no teatro, no século XIX, em 1821, o argentino Luís Ambrosio Morante estreia a peça La rebelión de Tupac Amaru, em meio ao fervor dos movimentos independentistas, o dramaturgo vem na esteira daqueles que o consideram o pai dos movimentos de emancipação; no século XX, sua imagem também é amplamente aproveitada: o argentino Osvaldo Dragún, em 1957, e o chileno Sergio Arrau, em 1980, evocam, respectivamente em Tupac Amaru e Tríptico de Tupac Amaru, a simbologia da rebelião para discutir os impasses de sua contemporaneidade imersa nos contextos de repressão e violência. O percurso deste personagem na história da cultura nos coloca uma questão fundamental e que está amplamente trabalhada na obra de Maria Ligia Prado e Gabriela Pellegrino: para além do sucesso ou do fracasso de alguns projetos, a importância simbólica destas personagens é também mola propulsora da história e ultrapassa sua trajetória.

É assim com Simón Bolívar, que morre desencantado e desacreditado a caminho do exílio e que, poucos anos depois, é celebrado no contexto de emancipação da Venezuela como herói nacional. É assim com Juan Domingo Perón que encontra apoiadores desde a extrema esquerda à extrema direita, em desdobramentos do chamado peronismo que ele jamais poderia prever e que censura posteriormente em seu retorno à Argentina. É assim com José Martí, evocado por Fidel Castro como mentor intelectual da revolução cubana de 1959, e Augusto César Sandino, mártir da revolução sandinista na Nicarágua dos anos 60.

As autoras também resgatam outras personagens menos conhecidas, abrilhantando o livro com suas histórias que, mesmo não tendo a mesma reverberação dos generais e letrados, nos convidam a pensar estes grandes debates históricos e sociais em casos como o de Policarpa Salavarrieta. Nascida no território que hoje compreende a Colômbia, Pola, como era conhecida, colhia informações dos realistas, nas casas onde trabalhava como costureira, e as repassava aos guerrilheiros emancipacionistas. Acabou fuzilada em Bogotá depois de descoberta. Sua execução fora registrada em um quadro de pintor anônimo, dando a dimensão da comoção causada por sua morte.

O século XX é abordado a partir de sua gama de discussões intensas e novas maneiras de conceber a América Latina. Inicia-se a análise com a revolução mexicana em sua multiplicidade de discussões, reivindicações e confrontos, passando pela efervescência social dos anos 60, pós-revolução cubana, nos intensos debates culturais sobre o papel da arte na revolução e os conflituosos limites do engajamento, no âmbito da literatura (ao retomar o boom latinoamericano e as polêmicas divergências de seus escritores) e da música (a partir das discussões sobre a canção engajada).

O Brasil, como parte integrante da América Latina, aparece recorrentemente, não mais 
sendo contraposto a uma "entidade", mas integrando os processos, como a ação na Guerra do Paraguai (1864-1870), ou refletindo criticamente sobre experiências partilhadas. No capítulo "Ditaduras militares e sociedade civil", as autoras partem de uma reflexão deste processo no âmbito da América Latina para depois pensarem as especificidades dos regimes militares em Chile, Argentina e Peru. O leitor brasileiro, munido de maior repertório quanto aos processos aqui ocorridos, pode pensar, a partir das menções feitas pelas autoras, as similaridades, diferenças e os ecos no presente deste episódio que são comuns a todas as nações que viveram a experiência do autoritarismo.

A linguagem fluida, preocupação das autoras para ampliar o público leitor, se une a uma narrativa contínua que, para além do brilhante encadeamento que torna a leitura ainda mais prazerosa, proporciona a percepção de que algumas questões fundamentais são recorrentes nos debates sociais e que não são superadas, sobretudo a questão indígena, que aparece desde Tupac Amaru, passando pelas reformas liberais e a dissolução dos pueblos indígenas e encontra eco nas tentativas de modernização da virada do século XIX para o XX e na revolução mexicana.

Esta História da América Latina de Maria Ligia Prado e Gabriela Pellegrino proporciona ao leitor ávido de conhecer as questões os personagens e os principais debates da história latino-americana, um primeiro encontro que o coloca em contato com as grandes narrativas (guerras, batalhas, revoluções), mas também com estas personagens, como a rebelde Pola, o audacioso Calfucurá e a reluzente Evita Perón, quase sempre tratadas à margem - quando tratados - e que aqui ganham espaço, mostrando como estas biografias podem nos oferecer uma visão mais dinâmica da história. Para os leitores já habituados com as temáticas discutidas, a leitura é igualmente prazerosa, pois a continuidade da narrativa e a maneira como estes "destinos coletivos" se articulam com estes sujeitos resgatados pelas autoras, possibilitam uma reflexão sobre a própria ideia de história e suas complexas articulações. 